\title{
Antitumor activity of nifurtimox is enhanced with tetrathiomolybdate in medulloblastoma
}

\author{
KAREN S. KOTO ${ }^{1}$, PAMELA LESCAULT ${ }^{3}$, LAURENT BRARD ${ }^{4}$, KYUKWANG KIM $^{4}$, \\ RAKESH K. SINGH ${ }^{4}$, JEFF BOND ${ }^{3}$, SHARON ILLENYE ${ }^{2}$, MARNI A. SLAVIK ${ }^{2}$, \\ TAKAMARU ASHIKAGA ${ }^{1,5}$ and GISELLE L. SAULNIER SHOLLER ${ }^{1,2}$
}

\author{
${ }^{1}$ Vermont Cancer Center, Departments of ${ }^{2}$ Pediatrics, ${ }^{3}$ Microbiology and Molecular Genetics, \\ University of Vermont College of Medicine, Burlington, VT; ${ }^{4}$ Department of Obstetrics and Gynecology, \\ Women and Infants Hospital of RI, Alpert Medical School of Brown University, Providence, RI; \\ ${ }^{5}$ Department of Medical Biostatistics, Vermont Cancer Center, University of Vermont, Burlington, VT, USA
}

Received November 22, 2010; Accepted January 17, 2011

DOI: $10.3892 /$ ijo.2011.971

\begin{abstract}
Medulloblastoma, a neuroectodermal tumor arising in the cerebellum, is the most common brain tumor found in children. We recently showed that nifurtimox induces production of reactive oxygen species (ROS) and subsequent apoptosis in neuroblastoma cells both in vitro and in vivo. Tetrathiomolybdate (TM) has been shown to decrease cell proliferation by inhibition of superoxide dismutase-1 (SOD1). Since both nifurtimox and TM increase ROS levels in cells, we investigated whether the combination of nifurtimox and TM would act synergistically in medulloblastoma cell lines (D283, DAOY). Genome-wide transcriptional analysis, by hybridizing RNA isolated from nifurtimox and TM alone or in combination treated and control cells (D283) on Affymetrix exon array gene chips was carried out to further confirm synergy. We show that nifurtimox and $\mathrm{TM}$ alone and in combination decreased cell viability and increased ROS levels synergistically. Examination of cell morphology following drug treatment (nifurtimox + TM) and detection of caspase-3 activation via Western blotting indicated that cell death was primarily due to apoptosis. Microarray data from cells treated with nifurtimox and TM validated the induction of oxidative stress, as many Nrf2 target genes (HMOX1, GCLM, SLC7A11 and SRXN1) $\left(\mathrm{p}<10^{-5}\right)$ were upregulated. Other genes related to apoptosis, oxidative stress, DNA damage, protein folding and nucleosome formation were differentially involved in cells following treatment with nifurtimox + TM. Taken together, our results suggest nifurtimox and TM act synergistically in medulloblastoma cells in vitro, and that this combination warrants further studies as a new treatment for medulloblastoma.
\end{abstract}

Correspondence to: Dr Giselle L. Saulnier Sholler, Department of Pediatrics, FAHC-Smith 559, 111 Colchester Ave., Burlington, VT 05401, USA

E-mail: gsholler@uvm.edu

Key words: medulloblastoma, nifurtimox, apoptosis, reactive oxygen species, tetrathiomolybdate

\section{Introduction}

Medulloblastoma is the most common malignant brain tumor in children and accounts for $17 \%$ of all brain tumors in children 0-14 years old (1). Each year about five hundred children in the US are affected by the disease (2). Many of these children are less than 3 years old at diagnosis. These patients have a reduced 5-year survival rate or increased long-term morbidity. The overall 5-year survival rates range from 40 to $70 \%$, with the lower rates corresponding to younger children. Current front-line treatments, which include intensive multiagent chemotherapy, surgical resection, and craniospinal radiation, often leave these patients with progressive neurocognitive and neuroendocrine defects (3-5). Despite these treatments, approximately one third of patients have recurrent disease. Therefore, novel, well-tolerated, effective treatments are needed to increase survival and prevent relapse without severe long-term toxicities.

Reactive oxygen species (ROS) are products of normal metabolism, and can also be induced by xenobiotic exposure. Depending on their concentration, ROS can lead to different outcomes for the cell because of their ability to modify many intracellular signaling pathways, as well as cause non-specific damage to DNA, lipids, and proteins (6). Oxidative stress activates the Nrf2 pathway, which activates a battery of genes involved in detoxification and prevention of free radical formation to protect the cell and facilitate cell survival (7). Under conditions of normal redox homeostasis, the cell maintains a balance between ROS generation or oxidative stress and antioxidant and repair defense mechanisms (8). At low levels, ROS can cause cell proliferation, while at high levels, ROS cause cytotoxicity, inhibition of cell proliferation, and induction of apoptosis (9). In order to upset this balance so that an overproduction of ROS leads to apoptosis, it is necessary to deliver an excess amount of ROS to cells (9). This is the strategy employed when utilizing exogenous ROSgenerating drugs to treat tumor cells (10). In general, tumor cells are more active than normal cells in the production of $\mathrm{O}^{2-}$ and are under intrinsic oxidative stress, which makes them rely more heavily on cellular antioxidant enzymes (11). Because 
of this, tumor cells are more susceptible to excessive oxidative stress induced by xenobiotic or chemotherapeutic agents (9). Under excess oxidative stress due to chemotherapeutic agents, the normal cellular mechanisms that regulate ROS, including cellular antioxidant systems such as SOD, glutathione, thioredoxin, and sulfiredoxin, and repair mechanisms, are unable to maintain cellular redox homeostasis $(9,11)$. The resulting overburden of ROS therefore leads to cell death (10).

One drug that generates the production of ROS is nifurtimox. Nifurtimox is a nitroheterocyclic compound that undergoes cellular reduction to nitro anion free radicals, hydrogen peroxide, and superoxide free radicals, which generate ROS (12-14). Originally nifurtimox was used to treat Chagas disease, which is caused by the parasite Trypanosoma cruzi (12). We previously reported a patient with neuroblastoma whose tumor appeared to respond to nifurtimox while undergoing conventional salvage chemotherapy (15). Subsequently we identified that nifurtimox causes ROS production, cytotoxicity and apoptosis of neuroblastoma cells in culture and in mouse xenograft models (16). Further, the in vitro cytotoxicity of nifurtimox in neuroblastoma cells is dependent on ROS generation (16). This led to a phase I clinical trial investigating the use of nifurtimox to treat pediatric patients with neuroblastoma where we determined the maximum tolerated dose (MTD) and its toxicity profile (76). Because nifurtimox is used to treat Chagas disease in the brain, it is known to cross the blood-brain barrier (12). It is readily absorbed after oral treatment with relatively low toxicity (17). As neuroblastoma and medulloblastoma are both tumors of the neuroectoderm, we hypothesized that nifurtimox might have the same cytotoxic effect on medulloblastoma cells as neuroblastoma cells.

Combining drugs that increase the level of ROS could potentially synergize the effects of nifurtimox on cell death. By increasing the amount of oxidative stress, the imbalance between the cellular oxidant species production and the antioxidant capability would be further increased. In combination with exogenous ROS-producing agents, drugs that reduce antioxidant capability could be used. Because of the increased oxidative stress in cancer cells, these cells are more vulnerable to antioxidant inhibition than normal cells (9). Deletion of the antioxidant gene superoxide dismutase-1 (SOD1) in Trypanosoma brucei has shown to increase sensitivity to nifurtimox (18). SOD1 is a copper/zinc enzyme found in the cytoplasm that converts superoxide into hydrogen peroxide and molecular oxygen, thereby maintaining low steady-state levels of superoxide (19-21). Deletion or inhibition of SOD1 results in an accumulation of superoxide in the cells (19-21). One way to inhibit SOD1 is by treatment with tetrathiomolybdate (TM), a copper chelater (22). By binding to copper, TM inhibits angiogenesis and SOD1 (23). TM is currently used to treat Wilson's disease and is a potent anti-angiogenic and anti-tumorigenic agent in mouse models. Based on these findings TM is being evaluated in human clinical oncology trials $(22,24-28)$. In addition, high levels of SOD1 in tumors has been correlated with poor prognosis in medulloblastoma patients, making TM a good candidate for medulloblastoma treatment (29). By combining nifurtimox and TM to treat tumor cells, ROS are generated and antioxidant defense mechanisms are impaired, resulting in an accumulation of ROS. Our hypothesis is that this excess of ROS created by the nifurtimox and TM combination treatment causes medulloblastoma cells to undergo apoptosis. A similar approach of combining an exogenous ROS-producing agent, arsenic trixoide, with a SOD1 inhibitor, 2-methoxyestradiol, has been shown to induce apoptosis of leukemia cells (30). TM has also been shown to cross the blood-brain barrier (31), making it a viable option for medulloblastoma treatment and reasonable to test it in combination with nifurtimox.

In our current study, we investigated the effects of nifurtimox treatment alone and in combination with TM on medulloblastoma cells. We found that nifurtimox and TM work synergistically to increase cellular levels of ROS and subsequent cell death in preclinical in vitro medulloblastoma cell lines. Induction of oxidative stress was further confirmed by gene expression profiles of medulloblastoma cells treated with nifurtimox and nifurtimox in combination with TM. These findings warrant further study to develop the combination of nifurtimox and $\mathrm{TM}$ as a potential treatment for medulloblastoma.

\section{Materials and methods}

Reagents. Nifurtimox (synthesized in the laboratory of Dr L. Brard, Women and Infants Hospital of RI/Brown University, Providence, RI) was dissolved in dimethyl sulfoxide (DMSO) as a $10 \mathrm{mg} / \mathrm{ml}$ stock and stored in aliquots at $-20^{\circ} \mathrm{C}$. TM (Sigma, St. Louis, MO) was dissolved in sterile water and stored in aliquots at $-20^{\circ} \mathrm{C}$. N-acetyl-L-cysteine (NAC) (Sigma, St. Louis, MO) was dissolved in RPMI (Mediatech) as an $800 \mathrm{mM}$ stock and made fresh for each experiment.

Cell culture and treatment. The human medulloblastoma cell lines D283 (ATCC HTB-185) and DAOY (ATCC HTB-186) were maintained at $37^{\circ} \mathrm{C}$ in a $5 \% \mathrm{CO}_{2}$, humidified incubator in RPMI-1640 media (Mediatech) supplemented with $10 \%$ (v/v) fetal bovine serum (Gibco), 100 units/ml penicillin and $100 \mu \mathrm{g} / \mathrm{ml}$ streptomycin. Cells were grown to $75 \%$ confluency in $100 \mathrm{~mm}$ plates or T75 flasks. Cells were treated with nifurtimox $(0,10,20 \mu \mathrm{g} / \mathrm{ml})$ or TM $(0,1,6.25 \mu \mathrm{g} / \mathrm{ml})$ or the combination of $10 \mu \mathrm{g} / \mathrm{ml}$ nifurtimox and $6.25 \mu \mathrm{g} / \mathrm{ml} \mathrm{TM}$ for 16-48 $\mathrm{h}$ for caspase activation studies.

Cell viability assay. Cell viability was measured with Calcein AM (Invitrogen, Carlsbad, CA). Calcein AM (a non-fluorescent molecule) is hydrolyzed by endogeous esterase into the highly negatively charged green fluorescent calcein. The fluorescent calcein is retained in the cytoplasm in live cells. Relative amount of Calcein AM directly corresponds to cell membrane integrity and cellular toxicity. The amount of dye transported into live cells over a fixed period of time was quantified by Calcein AM. D283 and DAOY cells (10,000 cells/well) were cultured in 48-well plates for $24 \mathrm{~h}$ and then treated with nifurtimox $(10 \mu \mathrm{g} / \mathrm{ml}), \mathrm{TM}(6.25 \mu \mathrm{g} / \mathrm{ml})$ or the combination of nifurtimox $(10 \mu \mathrm{g} / \mathrm{ml})$ and TM $(6.25 \mu \mathrm{g} / \mathrm{ml})$ for $48 \mathrm{~h}$. For the NAC studies, cells were pretreated with $10 \mathrm{mM} \mathrm{NAC}$ for $2 \mathrm{~h}$, and nifurtimox $(10 \mu \mathrm{g} / \mathrm{ml})$, and TM $(6.25 \mu \mathrm{g} / \mathrm{ml})$ were subsequently added for the remaining 46-h of incubation. Vehicle-treated $\left(0.1 \%\right.$ DMSO or $\left.\mathrm{H}_{2} \mathrm{O}\right)$ cells were used as controls. After incubation, media was removed and fresh media without serum containing $2 \mu \mathrm{g} / \mathrm{ml}$ Calcein AM was added, then cells were incubated at $37^{\circ} \mathrm{C}$ for an additional 
$30 \mathrm{~min}$. Fluorescence was measured at 520em/485ex using a BMG Fluostar microplate reader.

Isobologram statistical analysis. Statistical analysis of the cell survival data consisted of background correction, normalization and estimation of parameters reflecting the dependence of cell survival on drug concentration. More precisely, the fluorescence intensity, $I$, for each well was modeled using

$I=\exp \left(\beta_{N f t x}^{1} c_{N f t x}+\beta_{N f t x}^{2} c_{N f f x}^{2}+\beta_{T M}^{1} c_{T M}+\beta_{T M}^{2} c_{T M}^{2}+\beta_{N f t x, T M}^{2} c_{T M} c_{N f t x}\right)(N-B)+B+\varepsilon$

where $B$ is the mean intensity obtained from eight wells containing cell culture medium but no cells or drugs, $N$ is the mean intensity obtained from four wells containing cells but no drugs, $c_{d r u g}, d r u g \in\{N f t x, T M\}$, is a drug concentration, and $\varepsilon$ is a normally distributed error. Model parameters, $\beta_{\text {drug }(s)}^{\text {order }}$,order $\in\{1,2\}$, were obtained using nonlinear parameter estimation.

Western blot analysis. Cells cultured in $100 \mathrm{~mm}$ plates were grown to $75 \%$ confluency and collected by scraping,re-suspended in E buffer (10 mM Tris pH 7.6, $50 \mathrm{mM} \mathrm{NaCl}, 5 \mathrm{mM}$ EDTA, $50 \mathrm{mM} \mathrm{NaF}, 0.1 \mathrm{mM} \mathrm{NaVO}{ }_{4}, 1 \%$ Triton, $10 \mu \mathrm{g} / \mathrm{ml}$ aprotinin, $10 \mu \mathrm{g} / \mathrm{ml}$ leupeptin, ABSF) and incubated on ice for $20 \mathrm{~min}$ to lyse the cells. Cell lysates were sonicated for $10 \mathrm{sec}$ and centrifuged at $14,000 \mathrm{rpm}$ for $20 \mathrm{~min}$ at $4^{\circ} \mathrm{C}$. Protein concentration was determined with Bio-Rad protein assay (Bio-Rad, Hercules, CA). Cell lysates were electrophoresed on a $12 \%$ SDS-polyacrylamide gel and blotted onto polyvinylidene fluoride (PVDF) membrane, pore size $0.45 \mu \mathrm{m}$ (Millipore). The blots were blocked with Aquablock (EastCoast Bio, New Berwick, ME) diluted 1:1 in PBS. The blots were probed with rabbit-derived antibody to cleaved caspase-3 and $\beta$-actin (Cell Signaling Technology, Beverly, MA). Protein bands were visualized using infrared dye-conjugated anti-rabbit secondary antibodies (LI-COR Biosciences, Lincoln,NE) and photographed using an Odyssey Infrared Imaging System (LI-COR Biosciences).

Measurement of ROS. Production of ROS was determined using dichlorodihydrofluorescein (DCF). Cells were pretreated with $25 \mu \mathrm{g} / \mathrm{ml} \mathrm{TM} 24 \mathrm{~h}$ prior to nifurtimox $(10 \mu \mathrm{g} / \mathrm{ml})$ treatment. For nifurtimox treatment, media was changed to RPMI without phenol red and with glutamine and then nifurtimox was added to a final concentration of $10 \mu \mathrm{g} / \mathrm{ml}$ using minimal lighting. DMSO was added to the control cells. Cells were incubated in the dark at $37^{\circ} \mathrm{C}$ for $20-30 \mathrm{~min}$. Carboxylated DCF (Invitrogen) (10 $\mathrm{mM}$ in DMSO and stored as a single use aliquot) was added to each foil protected flask to a final concentration of $20 \mu \mathrm{M}$. Cells were incubated in the dark at $37^{\circ} \mathrm{C}$ for $25-30 \mathrm{~min}$. Cells were suspended in Accutase (Phoenix Flow, San Diego, $\mathrm{CA}$ ) and incubated for $5 \mathrm{~min}$ at $37^{\circ} \mathrm{C}$. Cells were centrifuged and re-suspended in $500 \mu \mathrm{l}$ Accumax (Phoenix Flow) and $0.2 \%$ sodium azide. Fluorescence was measured by flow cytometry.

RNA extraction and microarray. D283 cells were treated with $10 \mu \mathrm{g} / \mathrm{ml}$ nifurtimox, $6.25 \mu \mathrm{g} / \mathrm{ml} \mathrm{TM}$, or the combination of $10 \mu \mathrm{g} / \mathrm{ml}$ nifurtimox and $6.25 \mu \mathrm{g} / \mathrm{ml}$ TM for $6 \mathrm{~h}$. Samples were treated in duplicate. RNA extraction was done using the RNeasy micro kit (Qiagen, Valencia, CA) following the manufacturer's instructions and eluted in Riboblock RNase inhibitor (Formentas). RIN's were $>9$. RNA (5 $\mu \mathrm{g})$ was hybridized to each chip, and hybridization was performed using Affymetrix GeneChip Human Exon 1.0 ST arrays.

Oligonucleotide array analysis. Raw oligonucleotide array data includes a collection of images, one for each oligonucleotide probe for each chip. Each image is summarized in one probe intensity by the Vermont Genetics Network Microarray Facility using Affymetrix GCOS software. All other calculations were performed using R $(32) /$ BioConductor $(33,34)$ tools. Probe set sample matrix expression statistics were calculated using the Robust multichip average (RMA) method of Speed and coworkers $(35,36)$, implemented in the aroma.affymetrix package of Bengtsson (37). Quality statistics were calculated using the simpleaffy (38) package. Differential expression statistics were analyzed in the context of annotation using Ingenuity Integrated Pathway Analysis. Sample groups are designated by $\mathrm{C}$ (control), N (nifurtimox alone), T (TM alone), or NT (nifurtimox and TM). Comparisons are designated by $<$ Query Sample Group $>m<$ Reference Sample Group $>$ (m for minus). For each transcript cluster we tested the null hypotheses that there is no differential expression for each pair of sample groups, that there is no main effect of nifurtimox

$$
\frac{N T+N-T-C}{2}=0,
$$

no main effect of TM

$$
\frac{N T+T-N-C}{2}=0,
$$

or no nifurtimox-TM interaction

$$
(N T-T)-(N-C)=0 .
$$

\section{Results}

Nifurtimox and TM induce apoptosis of medulloblastoma cells in culture. The effect of nifurtimox and TM on the growth of D283 and DAOY medulloblastoma cells in culture was investigated. As shown in Fig. 1, single agent nifurtimox (A) and TM (B) inhibit the growth of both cell lines in a concentration-dependent manner. When treated with nifurtimox (5 $\mu \mathrm{g} / \mathrm{ml})$, cell viability of both D283 and DAOY cells were not affected, but treatment with nifurtimox $(10 \mu \mathrm{g} / \mathrm{ml})$ decreased cell viability to $70 \%$ in D283 cells and $44 \%$ in DAOY cells. Further, after 48-h exposure to $20 \mu \mathrm{g} / \mathrm{ml}$ nifurtimox, cell viability of D283 cells decreased to $23 \%$ and DAOY cells to $13 \%$ compared to vehicle-treated controls. Similarly, cell viability of D283 and DAOY cells was also decreased in a concentrationdependent manner upon increasing treatments of TM (Fig. 1B). When treated with $3.125 \mu \mathrm{g} / \mathrm{ml}$ TM, cell viability of D283 and DAOY decreased to 81 and 55\% respectively. Upon treatment with $50 \mu \mathrm{g} / \mathrm{ml} \mathrm{TM}$ for $48 \mathrm{~h}$, cell viability of D283 and DAOY decreased to 35 and $59 \%$, respectively. Based on these results, the nifurtimox concentration required to reach $50 \%$ inhibition of growth $\left(\mathrm{GI}_{50}\right)$ after 48 -h treatment for these cell lines was estimated to be $8.4 \mu \mathrm{g} / \mathrm{ml}$ in D283 cells and $24.3 \mu \mathrm{g} / \mathrm{ml}$ in DAOY cells. Similarly, $\mathrm{GI}_{50}$ for TM after 48 -h treatment was estimated to be $22.3 \mu \mathrm{g} / \mathrm{ml}$ in D283 cells and $20.5 \mu \mathrm{g} / \mathrm{ml}$ in 
A

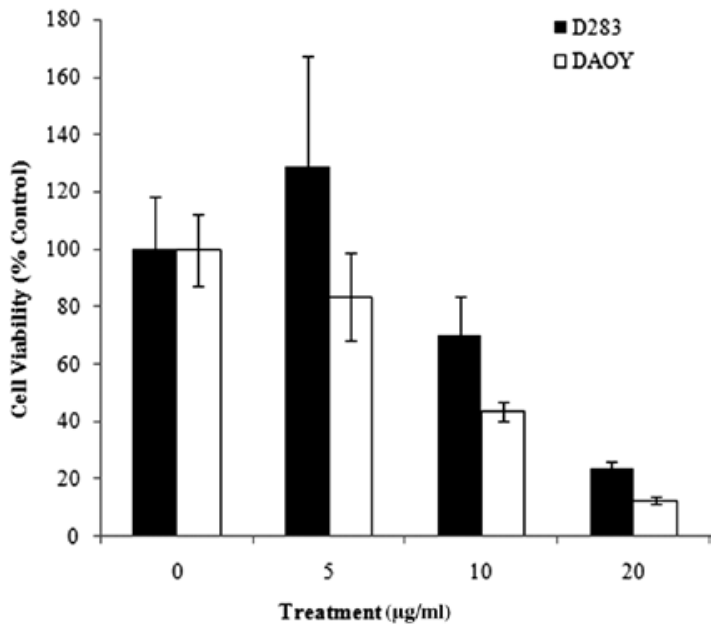

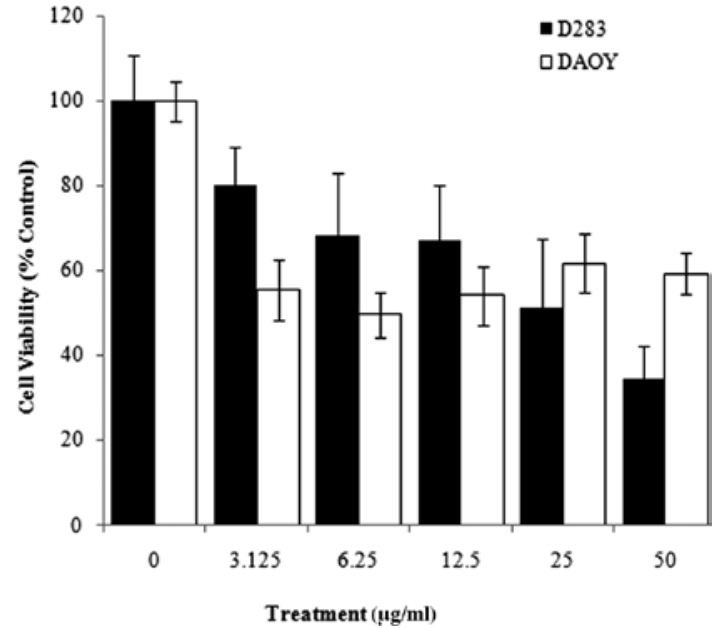

Figure 1. Nifurtimox and TM decrease medulloblastoma cell viability. D283 and DAOY medulloblastoma cells were incubated with increasing nifurtimox (A) and TM (B) concentrations in 48-well plates for $48 \mathrm{~h}$. Cell viability was quantified using Calcein AM and expressed as percent of vehicle control.

A

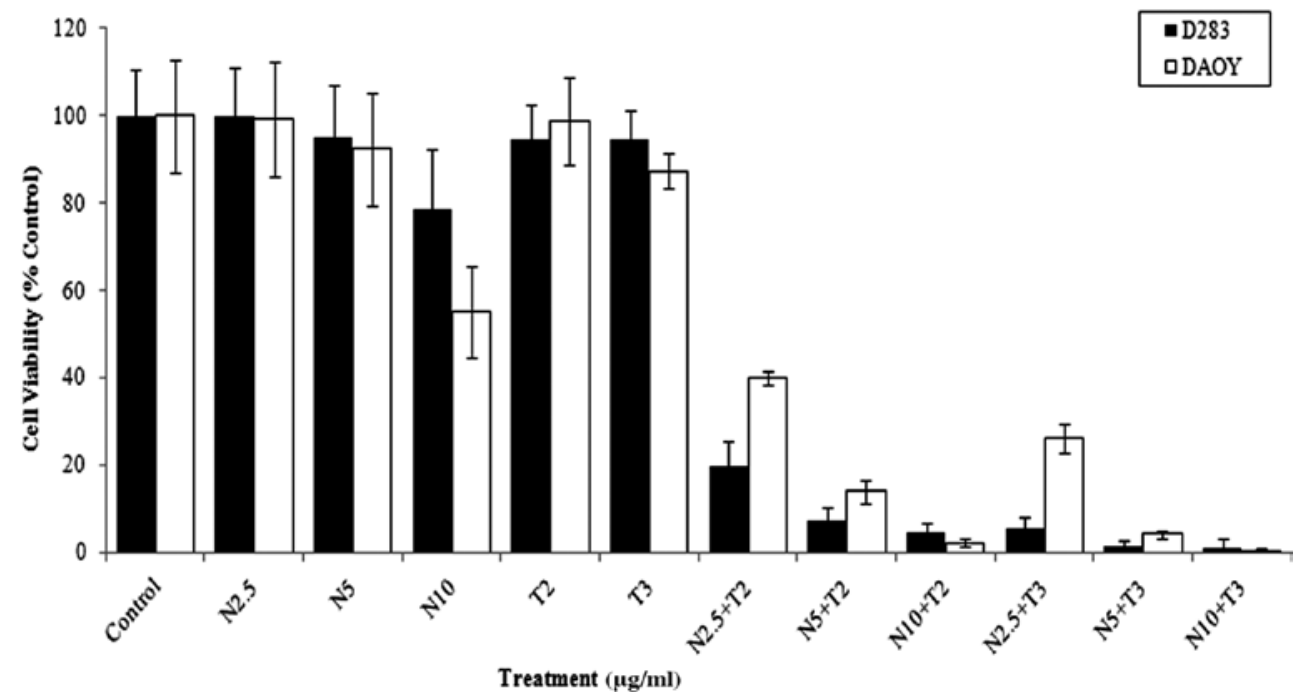

B

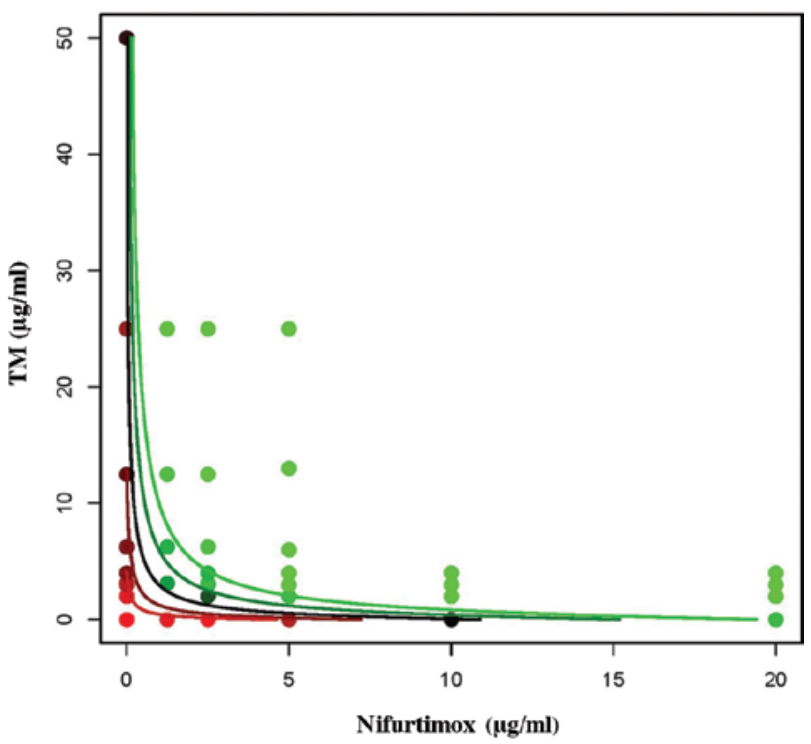

C

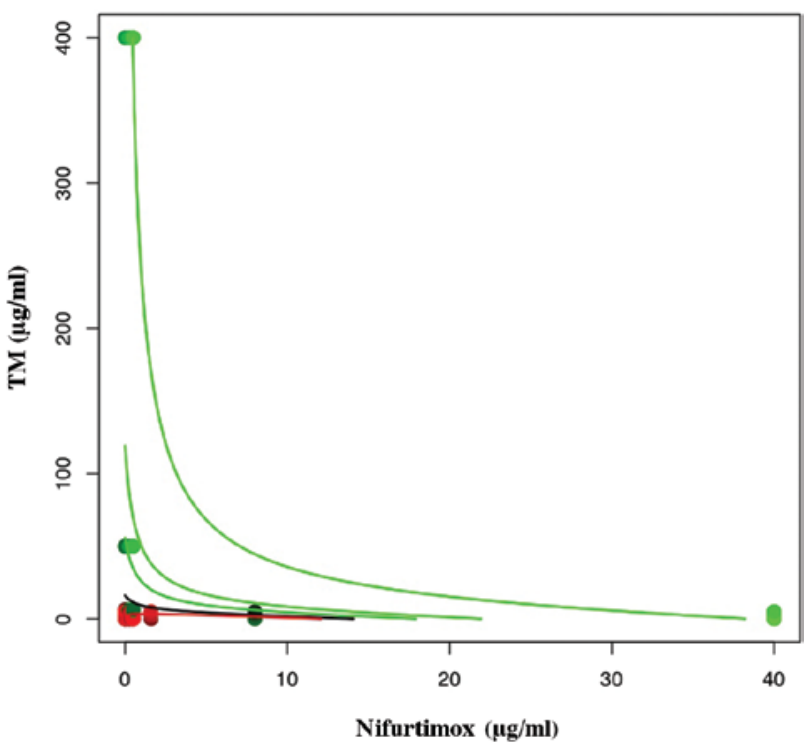

Figure 2. Nifurtimox and TM act synergistically to decrease medulloblastoma cell viability. (A), Combination of TM and nifurtimox at $48 \mathrm{~h}$. Cells were treated with nifurtimox and TM as described. Cell viability was measured by Calcein AM assay. Viability is expressed as percentage control. Isobolograms show that the combination of TM and nifurtimox is synergistic for DAOY (B) and D283 (C) medulloblastoma cells. Points express mean survival after treatment with one or two drugs. Survival is expressed by the point's color, ranging from 100\% survival (red) through $50 \%$ (black) to $0 \%$ (green). Contours represent the predictions obtained by fitting the model to data. Contour lines $(90 \%, 75 \%, 50 \%, 25 \%$, and $10 \%$ for DAOY; $90 \%, 50 \%, 10 \%, 1 \%$, and $0.0000001 \%$ for D283) are colored according to the same scale as the points, that is, with a successful fit the lines will go through points of the same color. 
A

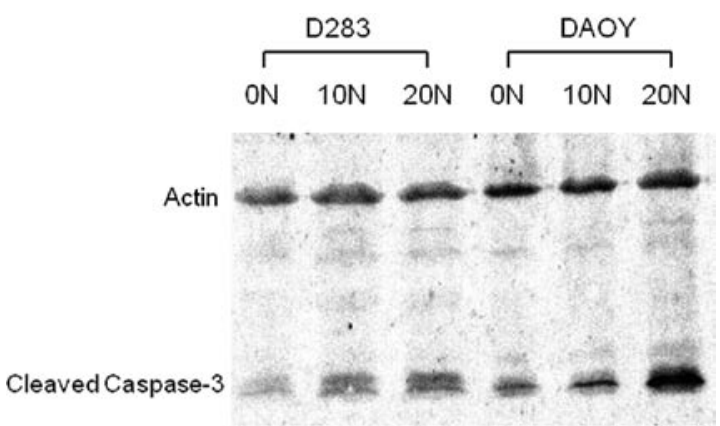

B

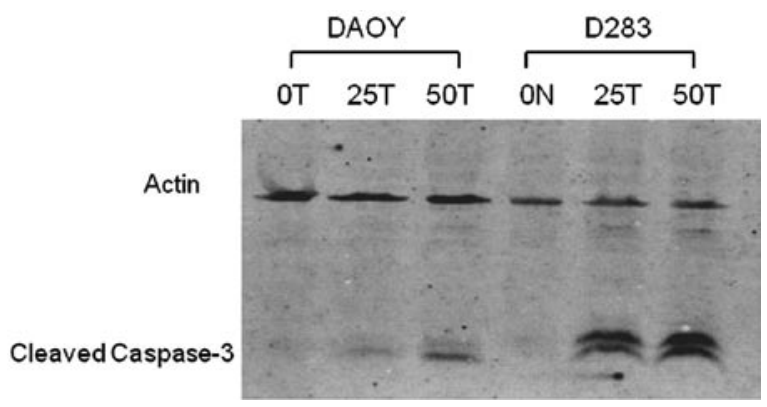

C

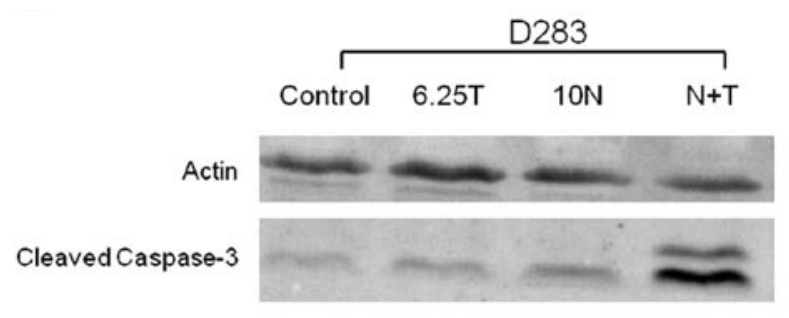

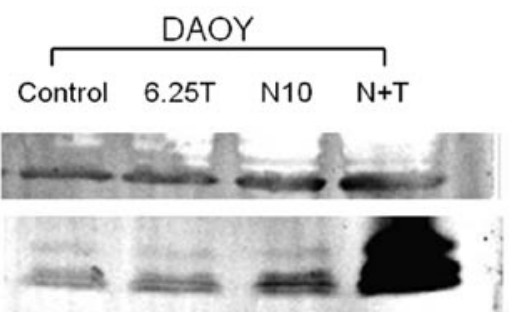

Figure 3. Nifurtimox induces apoptosis of medulloblastoma cells. Following nifurtimox $(\mathrm{N}), \mathrm{TM}(\mathrm{T})$, or combination treatments $(\mathrm{N}+\mathrm{T})$, cells were lysed for Western blot analysis and probed for actin and cleaved caspase-3. (A), D283 and DAOY cells were incubated with 0, 10, or $20 \mu \mathrm{g} / \mathrm{ml} \mathrm{nifurtimox}$ for $16 \mathrm{~h}$. (B), D283 and DAOY cells were treated with 0,25 , or $50 \mu \mathrm{g} / \mathrm{ml} \mathrm{TM}$ for $48 \mathrm{~h}$. (C), D283 and DAOY cells were incubated with vehicle, $6.25 \mu \mathrm{g} / \mathrm{ml} \mathrm{TM}, 10 \mu \mathrm{g} / \mathrm{ml}$ nifurtimox, or the combination for $16 \mathrm{~h}$.

DAOY cells. In contrast, normal epithelial cells in culture exposed to nifurtimox do not experience these cytotoxic effects (15).

To determine if the combination of nifurtimox and TM has synergistic effects on cell viability, various concentrations of nifurtimox and TM were used to treat D283 and DAOY cells. As single agents, $2.5-5 \mu \mathrm{g} / \mathrm{ml}$ nifurtimox and 2-3 $\mu \mathrm{g} / \mathrm{ml}$ TM did not alter cell viability at low doses (Fig. 2A). However, the combination of low doses of nifurtimox and TM greatly decreased cell viability (Fig. 2A). The addition of $1 \mu \mathrm{g} / \mathrm{ml} \mathrm{TM}$ decreased the $\mathrm{GI}_{50}$ of nifurtimox to $5.8 \mu \mathrm{g} / \mathrm{ml}$ (40\% decrease) in D283 and $1.2 \mu \mathrm{g} / \mathrm{ml}$ (95\% decrease) in DAOY cells. The combination of $2.5 \mu \mathrm{g} / \mathrm{ml}$ nifurtimox with $2 \mu \mathrm{g} / \mathrm{ml} \mathrm{TM}$ decreased cell viability to 20 and $40 \%$ as compared to vehicle-treated D283 and DAOY cells, respectively. At $5 \mu \mathrm{g} / \mathrm{ml}$ nifurtimox and $3 \mu \mathrm{g} / \mathrm{ml} \mathrm{TM}$, the cell viability was further decreased to 1 and $4 \%$ as compared to vehicle-treated D283 and DAOY cells, respectively. Further, the efficacy of the combination of nifurtimox and TM in the treatment of medulloblastoma was analyzed by performing isobologram analysis of cell viability for DAOY (Fig. 2B) and D283 (Fig. 2C) cells. Fig. 2B and C show the isobologram data for the combination of nifurtimox and TM at varying concentrations. Parameter estimation strongly suggests drug synergism for both cell lines $\left(\mathrm{p}<10^{-80}\right.$ and $\mathrm{p}<10^{-2}$ for DAOY and D283, respectively). Since the lines indeed go through points of the same color, with red lines going through red points and green lines going through green points, the model adequately describes the data.

Nifurtimox and TM in combination activate caspase-3 in medulloblastoma cells. To determine whether nifurtimox, TM and the combination of nifurtimox and TM decrease cell viability by inducing apoptosis, a Western blot analysis of lysates of drug-treated (single agent or in combination) vs. vehicle treated DAOY or D283 cells was performed to detect activated caspase- 3 , an initiator of the apoptotic cascade (39)
(Fig. 3). D283 and DAOY cells were exposed to $10 \mu \mathrm{g} / \mathrm{ml}$ nifurtimox for $16 \mathrm{~h}, 6.25 \mu \mathrm{g} / \mathrm{ml} \mathrm{TM}$ for $48 \mathrm{~h}$, and the combination of $10 \mu \mathrm{g} / \mathrm{ml} \mathrm{nifurtimox}$ and $6.25 \mu \mathrm{g} / \mathrm{ml} \mathrm{TM}$ for $16 \mathrm{~h}$. Caspase activation was indicated by the concentration-dependent presence of cleaved caspase- 3 when cells were treated with nifurtimox or TM alone. This caspase activation was not observed in vehicle-treated controls (Fig. 3A and B). When cells were treated with a combination of nifurtimox and TM, caspase-3 activation was increased as compared to vehicletreated controls and cells treated with each of the drugs alone (Fig. 3C).

The combination of nifurtimox and TM increases ROS in medulloblastoma cells. To determine if nifurtimox and TM produce ROS in medulloblastoma cells, D283 and DAOY cells were pretreated with $25 \mu \mathrm{g} / \mathrm{ml} \mathrm{TM}$ for $24 \mathrm{~h}$ and then treated with $10 \mu \mathrm{g} / \mathrm{ml}$ nifurtimox for 25-30 min. Cells were then incubated with carboxyl-DCF and fluorescence was measured by flow cytometry. Nifurtimox induced a 1.5 -fold change in the DAOY cells and a 1.4-fold change in the D283 cells (Fig. 4A and B). TM induced a 1.5 -fold change in the DAOY cells and a 1.3-fold change in the D283 cells (Fig. 4A and B). The combination of nifurtimox and TM induced a 3.1-fold change in the DAOY cells and a 1.6-fold change in the D283 cells, demonstrating increased levels of ROS in these cells (Fig. 4A and B).

To show that the cytotoxicity of nifurtimox was due to ROS, D283 and DAOY cells were pretreated with the antioxidant $\mathrm{N}$-acetyl-L-cysteine (NAC) $(10 \mathrm{mM})$ for $2 \mathrm{~h}$ and then treated with nifurtimox $(10 \mu \mathrm{g} / \mathrm{ml})$ or the combination of nifurtimox $(10 \mu \mathrm{g} / \mathrm{ml})$ and TM $(6.25 \mu \mathrm{g} / \mathrm{ml})$ for $48 \mathrm{~h}$ and cell viability was measured by Calcein AM assay. As shown in Fig. 4C, the viability of DAOY cells treated with NAC was the same as vehicle-treated cells, however, the viability of D283 cells was reduced $(20 \%)$ upon treatment with NAC $(10 \mathrm{mM})$. Further, as shown previously (Fig. 2A), treatment with nifurtimox 
A
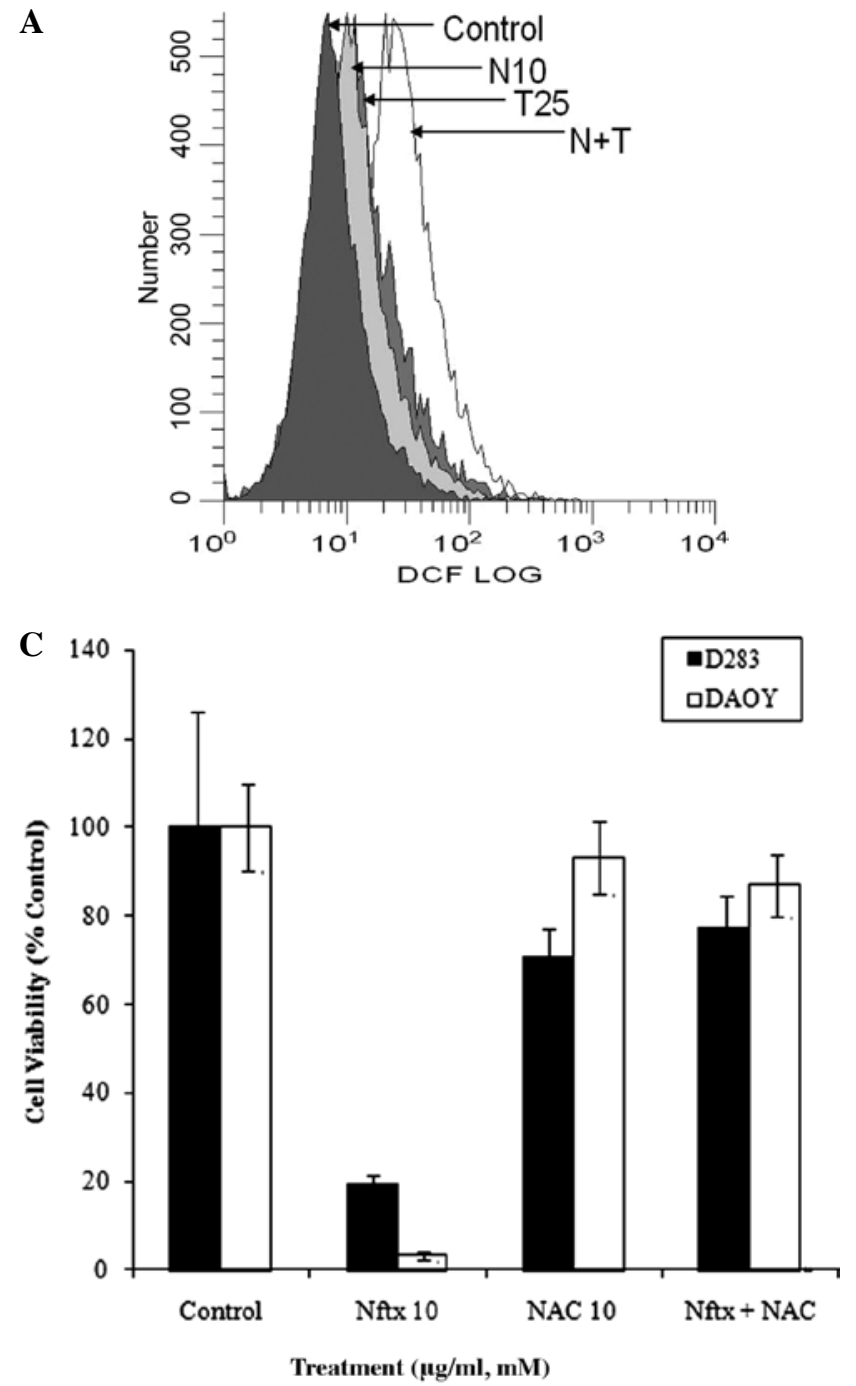

B
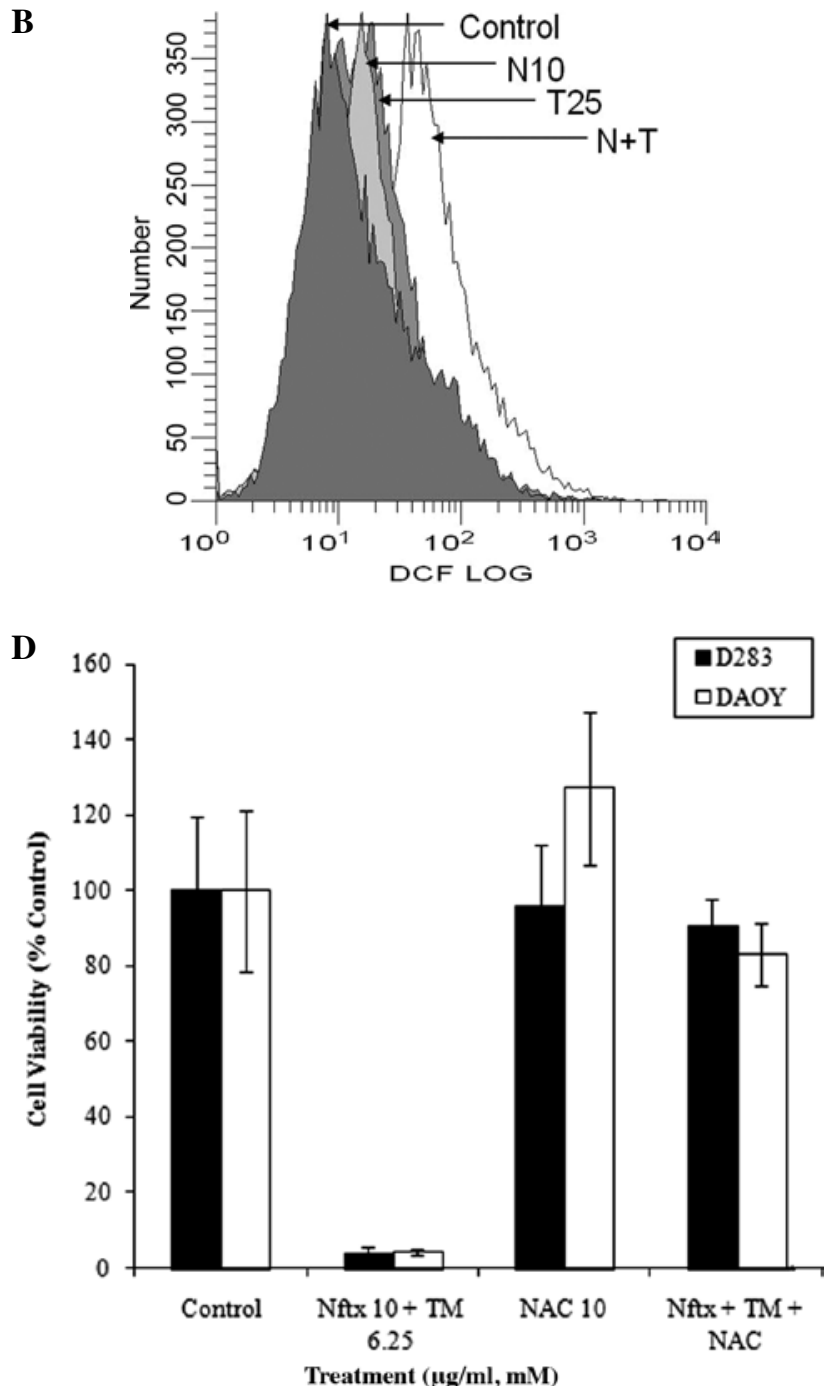

Figure 4. Nifurtimox induces formation of reactive oxygen species in medulloblastoma cells. (A and B), Cells were incubated with $10 \mu \mathrm{g} / \mathrm{ml}$ nifurtimox (10-N), $25 \mu \mathrm{g} / \mathrm{ml}$ TM $(25-\mathrm{N})$, or the combination of $10 \mu \mathrm{g} / \mathrm{ml}$ nifurtimox and $25 \mu \mathrm{g} / \mathrm{ml} \mathrm{TM}(\mathrm{N}+\mathrm{T})$ for $25-30$ min prior to treatment with carboxylated DCF. Cells were collected and analyzed by flow cytometry. (C), Cells were pre-incubated with $10 \mathrm{mM}$ NAC for $2 \mathrm{~h}$, then $10 \mu \mathrm{g} / \mathrm{ml}$ nifurtimox or the combination of $10 \mu \mathrm{g} / \mathrm{ml}$ nifurtimox and $6.25 \mu \mathrm{g} / \mathrm{ml} \mathrm{TM}$ was added. Cell viability was quantified after $48 \mathrm{~h}$ using Calcein AM.

or the combination of nifurtimox and TM decreased cell viability (Fig. 4D). When cells were pretreated with NAC (10 $\mathrm{mM})$ followed by nifurtimox $(10 \mu \mathrm{g} / \mathrm{ml})$, or nifurtimox $(10 \mu \mathrm{g} / \mathrm{ml})$ and TM $(6.25 \mu \mathrm{g} / \mathrm{ml})$, cell viability of DAOY and D283 cells recovered to the same level of controls, confirming that ROS activation indeed mediates cytotoxicity induced by nifurtimox and the combination of nifurtimox and TM in these medulloblastoma cell lines (Fig. 4D).

Nifurtimox treatment resulted in activation of the Nrf2 pathway. To investigate changes in gene expression caused by treatments with nifurtimox, TM, or the combination of nifurtimox and TM, Affymetrix exon arrays were performed on RNA isolated from treated and control D283 cells. D283 cells were treated with DMSO vehicle, $10 \mu \mathrm{g} / \mathrm{ml}$ nifurtimox, $6.25 \mu \mathrm{g} / \mathrm{ml} \mathrm{TM}$, or the combination of $10 \mu \mathrm{g} / \mathrm{ml}$ nifurtimox and $6.25 \mu \mathrm{g} / \mathrm{ml}$ TM for $6 \mathrm{~h}$, then RNA was isolated and exon arrays were performed.

Nrf2 target genes were non-randomly represented among genes judged differentially expressed. Genes differentially expressed in response to nifurtimox in either the absence
(NmC) or presence $(\mathrm{NTmT})$ of TM were identified based on a p-value threshold of 0.05 (Fig. 5A and B). The nonrandom representation of $\mathrm{Nrf} 2$ pathway genes was significant at $\mathrm{p}<3 \times 10^{-6}$ and $\mathrm{p}<2 \times 10^{-6}$, respectively (Fig. 5A-D). The response of these genes to nifurtimox was very similar in NmC and NTmT (Fig. 5C), such that the nonrandom representation of Nrf2 pathway genes among genes identified as differentially expressed using the main effect of nifurtimox was significant at $\mathrm{p}<3 \times 10^{-8}$. Nrf2 pathway genes responding to nifurtimox with a greater than 2-fold change included HMOX1, GCLM, SLC7A11, and SRXN1, which were significant at $\mathrm{p}<10^{-5}$ in the NmC, NTmT and main effect comparisons (Fig. 5D). Ingenuity pathways analysis (IPA) was used to generate the NRF2 pathway, which has been overlaid with relative gene expression levels of the main effect of nifurtimox (Fig. 6). Other differentially expressed genes included those involved in apoptosis, response to oxidative stress, response to DNA damage, protein folding, and nucleosome formation (Table I).

The results of the other comparisons were less clear. The range of response to nifurtimox was $<3$-fold compared with 6 -fold, and there was little correlation between $\mathrm{TmC}$ and 
A

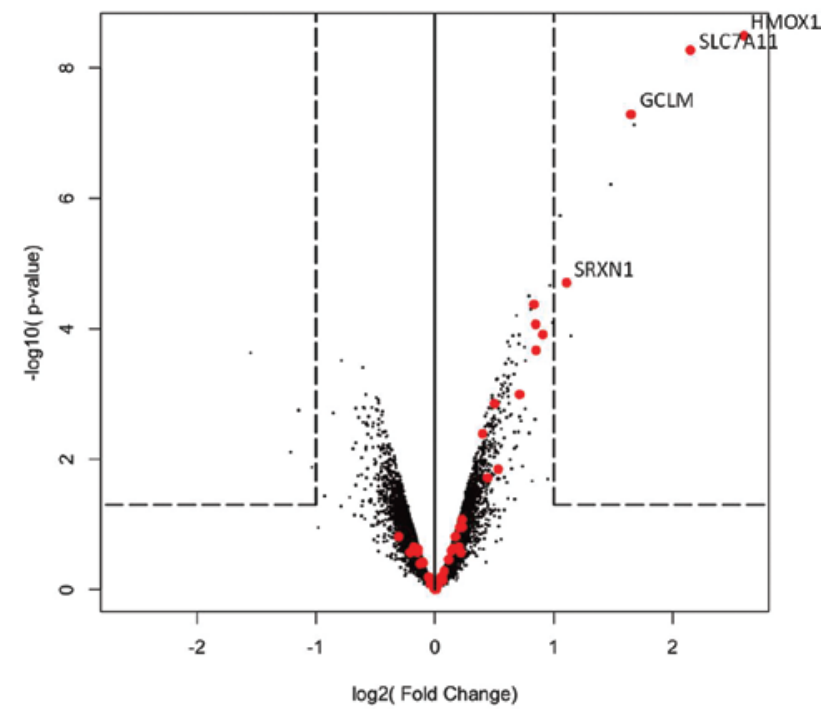

C

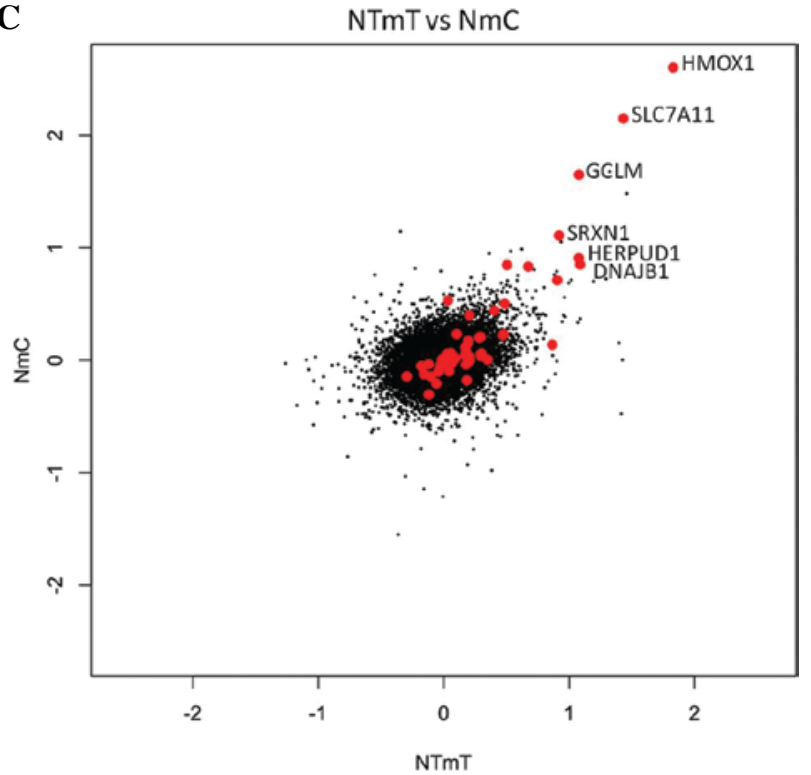

$\mathbf{E}$

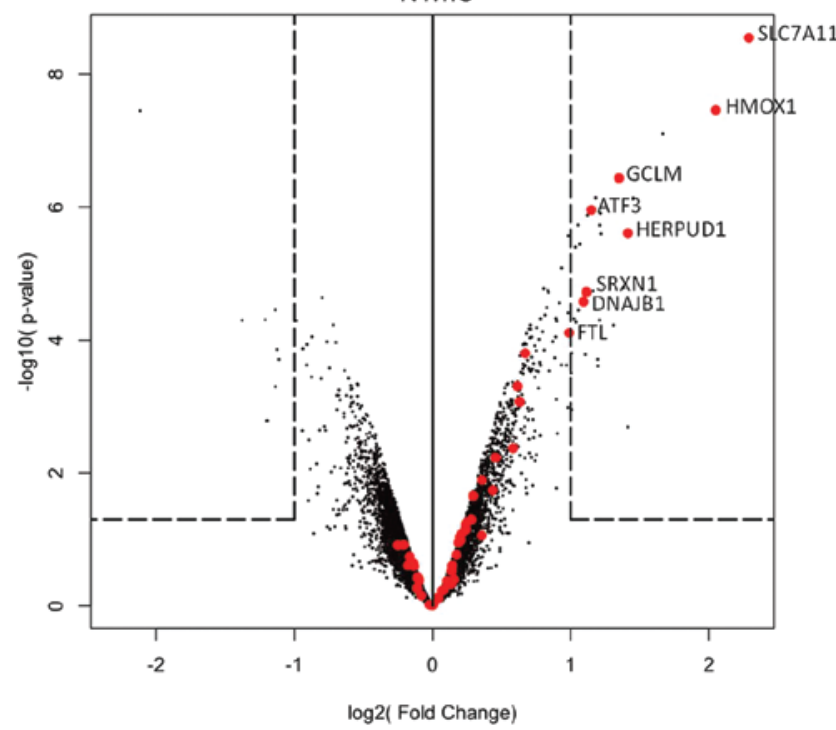

NTmN. It may be that the time scale was too short to have seen a widespread response to TM that mediates the synergism
B

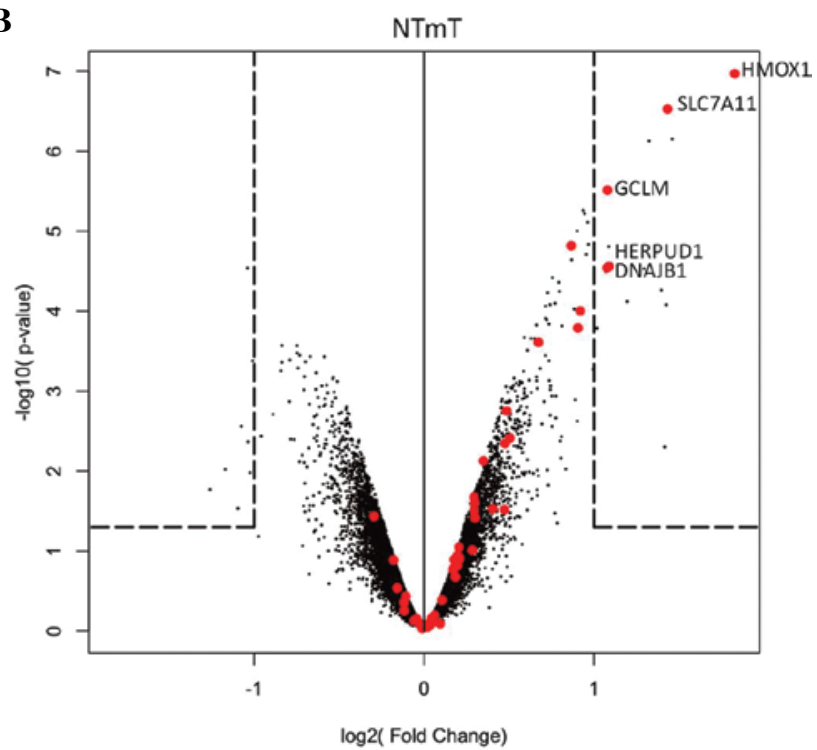

D

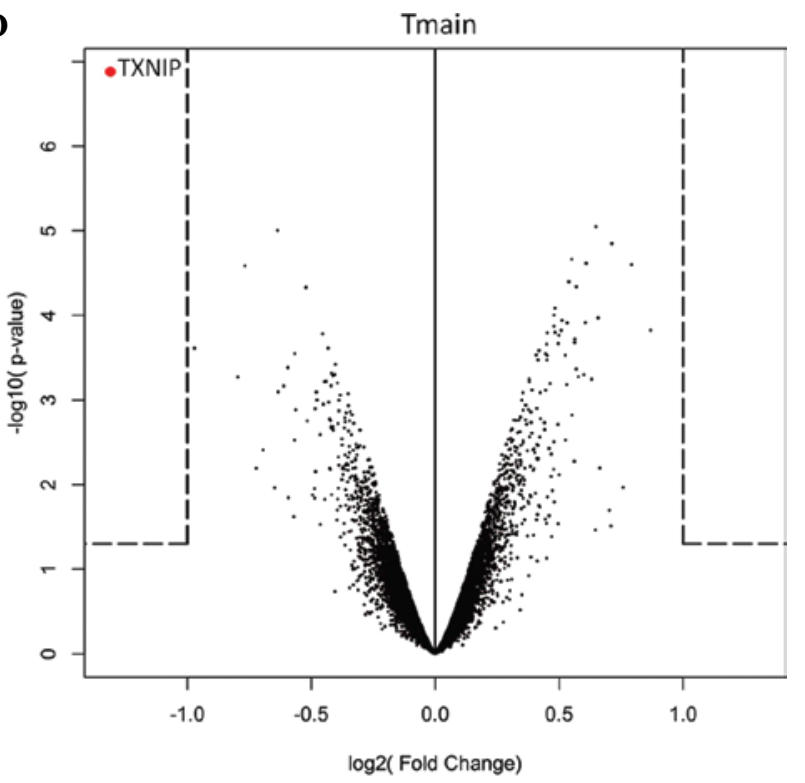

Figure 5. NRF2-mediated oxidative stress response pathway is activated by nifurtimox in either the absence (NmC) or the presence (NTmT) of TM. (A and B), Volcano plots representing the magnitude (horizontal axis) and statistical significance (vertical axis) of differential expression of each probe set (points) based on (A) NmC and (B) NTmT comparisons, respectively. Dashed lines bound regions having $\mathrm{p}<0.05$ and either 2 -fold increased (upper right) or 2-fold decreased (upper left) differential expression. Gene targets of the transcription factor NRF2 are colored in red. (C), Scatterplot representing the magnitude of differential expression in NmC and NTmT for each probe set. Gene targets of the transcription factor NRF2 are colored in red. (D), TXNIP is downregulated by TM in either the absence $(\mathrm{TmC})$ or the presence $(\mathrm{NTmN})$ of nifurtimox. Volcano plot shows differential expression and statistical significance of the main effect of TM; TXNIP is colored in red. (E), Volcano plot representing the magnitude (horizontal axis) and statistical significance (vertical axis) of differential expression of each probe set (points) based on NTmC. Dashed lines bound regions having $\mathrm{p}<0.05$ and either 2 -fold increased (upper right) or 2 -fold decreased (upper left) differential expression. Gene targets of the transcription factor NRF2 are colored in red.

seen at 24-48 h. Nonetheless TXNIP was down-regulated in both comparisons and was associated with an adjusted $\mathrm{p}$-value $<0.003$ (Fig. 5D). 


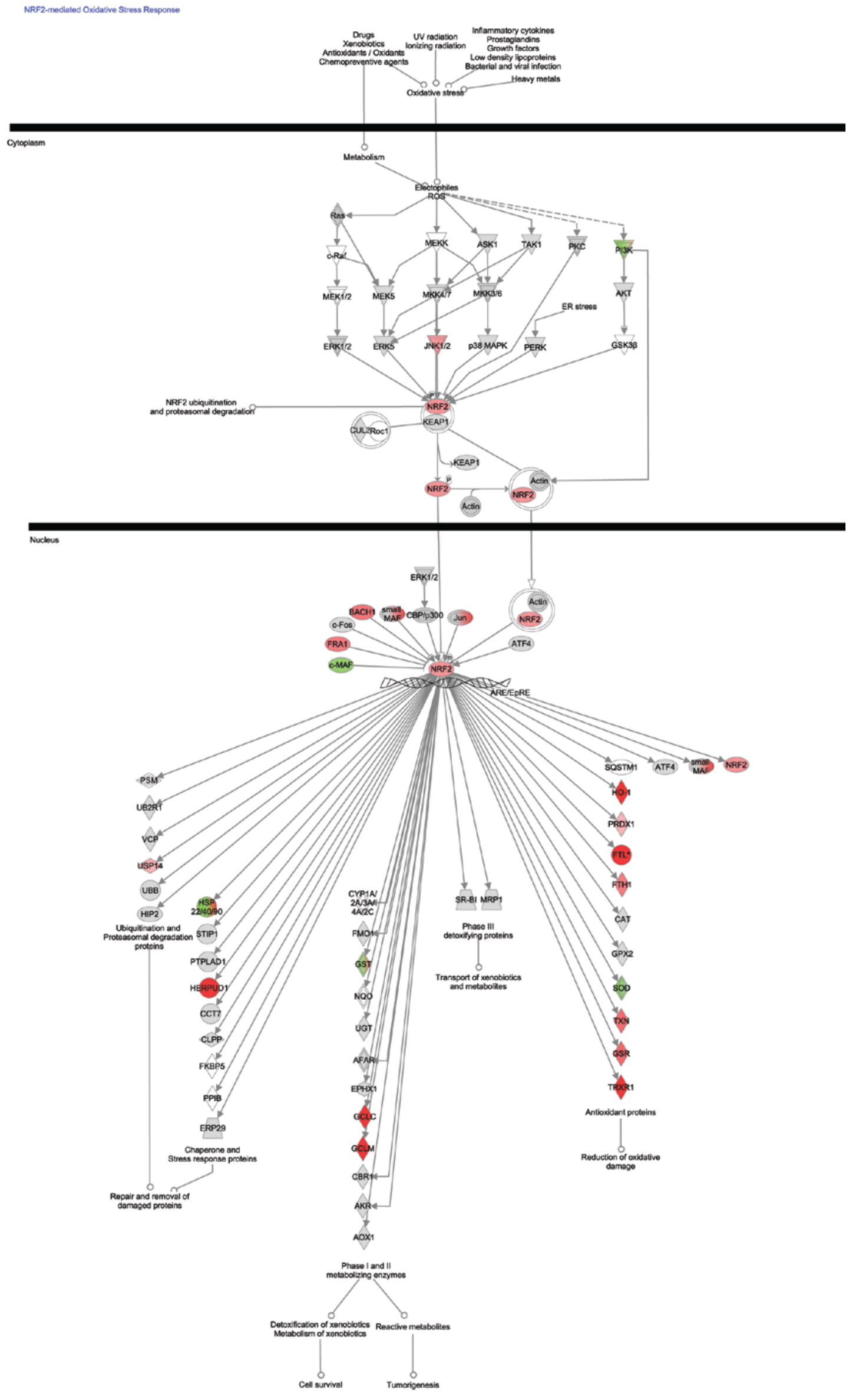

Figure 6. Canonical pathway analysis and differential expression induced by the main effect of nifurtimox. Data were analyzed through the use of Ingenuity Pathways Analysis (Ingenuity ${ }^{\circledR}$ Systems, www.ingenuity.com) and was used to generate the nuclear NRF2 pathway, which has been overlaid with relative gene expression levels of the main effect of nifurtimox. Red indicates up-regulation, and green indicates down-regulation. 
Table I. Genes involved in apoptosis, oxidative stress, DNA damage, protein folding, or nucleosome structure that are differentially expressed in $\mathrm{NmC}, \mathrm{TmC}$, or NTmC.

\begin{tabular}{|c|c|c|c|c|c|c|c|}
\hline Accession no. & Gene name & $\begin{array}{l}\mathrm{NmC} \\
\text { f.c. }\end{array}$ & $\underset{\mathrm{p}}{\mathrm{NmC}}$ & $\begin{array}{l}\mathrm{TmC} \\
\text { f.c. }\end{array}$ & $\underset{\mathrm{p}}{\mathrm{TmC}}$ & $\begin{array}{l}\mathrm{NTmC} \\
\text { f.c. }\end{array}$ & $\underset{\mathrm{p}}{\mathrm{NTmC}}$ \\
\hline \multicolumn{8}{|l|}{ Apoptosis } \\
\hline NM_002061 & Glutamate-cysteine ligase, modifier subunit (GCLM) & 3.13 & 0.0003 & 1.21 & 0.9997 & 2.55 & 0.0115 \\
\hline NM_002133 & Heme oxygenase (decycling) 1 (HMOX1) & 6.07 & 5E-05 & 1.17 & 0.9997 & 4.14 & 0.00201 \\
\hline NM_006472 & Thioredoxin interacting protein (TXNIP) & 1.49 & 0.453 & 2.11 & 0.196 & 4.34 & 0.00022 \\
\hline NM_006186 & Nuclear receptor subfamily 4 group A member 2 (NR4A2) & 1.27 & 0.732 & 1.18 & 0.9997 & 2.27 & 0.00198 \\
\hline NM_004417 & Dual specificity phosphatase 1 (DUSP1) & 1.31 & 0.732 & 1.18 & 0.9997 & 2.31 & 0.00291 \\
\hline NM_019058 & DNA-damage-inducible transcript 4 (DDIT4) & 1.11 & 0.999 & 0.87 & 0.9997 & 2.29 & 0.0413 \\
\hline NM_004083 & DNA-damage-inducible transcript 3 (DDIT3) & 1.61 & 0.621 & 1.24 & 0.9997 & 2.48 & 0.0221 \\
\hline NM_015675 & Growth arrest and DNA-damage-inducible, beta (GADD45B) & 1.03 & 0.999 & 1.15 & 0.9997 & 2.09 & 0.00398 \\
\hline \multicolumn{8}{|c|}{ Oxidative stress/DNA damage/protein folding } \\
\hline NM_002061 & Glutamate-cysteine ligase, modifier subunit (GCLM) & 3.13 & 0.0003 & 1.21 & 0.9997 & 2.55 & 0.00137 \\
\hline NM_080725 & Sulfiredoxin 1 homolog (SRXN1) & 2.16 & 0.0506 & 1.14 & 0.9997 & 2.16 & 0.0132 \\
\hline NM_002133 & Heme oxygenase (decycling) 1 (HMOX1) & 6.07 & $5 \mathrm{E}-05$ & 1.17 & 0.9997 & 4.14 & 0.00022 \\
\hline NM_006472 & Thioredoxin interacting protein (TXNIP) & 1.49 & 0.453 & $\underline{2.11}$ & 0.196 & 4.34 & 0.00022 \\
\hline NM_001031716 & $\begin{array}{l}\text { Oligonucleotide/oligosaccharide-binding fold containing } 2 \mathrm{~A} \\
\text { (OBFC2A) }\end{array}$ & 1.2 & 0.999 & 1.61 & 0.748 & 2.24 & 0.0132 \\
\hline NM_004417 & Dual specificity phosphatase 1 (DUSP1) & 1.31 & 0.732 & 1.18 & 0.9997 & 2.31 & 0.00291 \\
\hline NM_004083 & DNA-damage-inducible transcript 3 (DDIT3) & 1.61 & 0.621 & 1.24 & 0.9997 & 2.48 & 0.0221 \\
\hline NM_080725 & Sulfiredoxin 1 homolog (S. cerevisiae) (SRXN1) & 2.16 & 0.0506 & 1.14 & 0.9997 & 2.16 & 0.0132 \\
\hline NM_014685 & $\begin{array}{l}\text { Homocysteine/ER stress-inducible, ubiquitin-like domain } \\
\text { member } 1 \text { (HERPUD1) }\end{array}$ & 1.87 & 0.109 & 1.26 & 0.9997 & 2.66 & 0.00314 \\
\hline NM_001040619 & Activating transcription factor 3 (ATF3) & 1.1 & 0.999 & 1.22 & 0.9997 & 2.22 & 0.00245 \\
\hline NM_014331 & Solute carrier family 7, member 11 (SLC7A11) & 4.44 & $5 \mathrm{E}-05$ & 1.81 & 0.21 & 4.89 & 5.3E-05 \\
\hline NM_006145 & DnaJ (Hsp40) homolog, subfamily B, member 1 (DNAJB1) & 1.8 & 0.149 & 1 & 0.9997 & 2.13 & 0.016 \\
\hline NM_012328 & DnaJ (Hsp40) homolog, subfamily B, member 9 (DNAJB9) & 1.47 & 0.284 & 1.05 & 0.9997 & 2.05 & 0.00414 \\
\hline NM_007034 & DnaJ (Hsp40) homolog, subfamily B, member 4 (DNAJB4) & 3.2 & 0.0004 & 1.27 & 0.9997 & 3.18 & 0.00037 \\
\hline \multicolumn{8}{|c|}{ Nucleosome formation } \\
\hline NM_175055 & Histone cluster 3, H2bb (HIST3H2BB) & 1.14 & 0.999 & 1.12 & 0.9997 & $\underline{2.308}$ & 0.137 \\
\hline NM_003528 & Histone cluster 2, H2be (HIST2H2BE) & 1.19 & 0.999 & 1.23 & 0.9997 & $\underline{2.208}$ & 0.0186 \\
\hline NM_003522 & Histone cluster 1, H2bf (HIST1H2BF) & 1.259 & 0.931 & 1.36 & 0.9997 & $\underline{2.1}$ & 0.0132 \\
\hline NM_005322 & Histone cluster 1, H1b (HIST1H1B) & 1.299 & 0.999 & 1.41 & 0.9997 & $\underline{2.28}$ & 0.0372 \\
\hline NM_003519 & Histone cluster 1, H2bl (HIST1H2BL) & 1.369 & 0.668 & 1.32 & 0.9997 & $\underline{2.01}$ & 0.0143 \\
\hline NM_003521 & Histone cluster 1, H2bm (HIST1H2BM) & 1.37 & 0.982 & 1.35 & 0.9997 & $\underline{2.75}$ & 0.0242 \\
\hline NM_003544 & Histone cluster 1, H4b (HIST1H4B) & 1.389 & 0.891 & 1.52 & 0.9997 & 2.18 & 0.0345 \\
\hline NM_003513 & Histone cluster 1, H2ab (HIST1H2AB) & 1.42 & 0.822 & 1.34 & 0.9997 & 2.31 & 0.0211 \\
\hline NM_003537 & Histone cluster 1, H3b (HIST1H3B) & 1.48 & 0.856 & 1.41 & 0.9997 & 2.57 & 0.0251 \\
\hline NM_003511 & Histone cluster 1, H2al (HIST1H2AL) & 1.81 & 0.402 & 1.53 & 0.9997 & $\underline{2.6}$ & 0.0211 \\
\hline NM_005320 & Histone cluster 1, H1d (HIST1H1D) & $\underline{2.04}$ & 0.0727 & 2.28 & 0.196 & 2.55 & 0.00443 \\
\hline
\end{tabular}

Table was constructed using GoTerms for apoptosis, oxidative stress, and response to DNA damage. Additional genes involved in these processes based on primary literature were added. Genes were chosen based on at least 2-fold change in one treatment, depicted in bold numbers. Treatment conditions include nifurtimox minus control ( $\mathrm{NmC}$ ), TM minus control (TmC), and nifurtimox and TM minus control (NTmC). Fold changes (f.c.) indicate sign fold changes, and p-values (p) represent adjusted p-values. Genes that are up-regulated are in black; genes that are down-regulated are underlined.

A subset of genes was differentially expressed in the $\mathrm{NTmC}$ as compared to $\mathrm{NmC}$ and TmC (Fig. 5E and Table I). Additional Nrf2 target genes, including HERPUD1, ATF3, and DNAJB1, additional stress-inducible molecular chaperones including DNAJB9 and DNAJB4, and other genes involved in apoptosis and DNA damage including DUSP1, OBFC2A, 
DDIT3, DDIT4, and GADD45B, were up-regulated by at least 2-fold change with adjusted p-values $<0.05$ (Fig. 5E and Table I). A large subset of histones were down-regulated by the nifurtimox and TM treatment, with adjusted p-values ranging from 0.004 to 0.136 .

\section{Discussion}

Our study investigated whether the combination of nifurtimox and TM treatment would lead to an increase in ROS production and subsequent cell death in medulloblastoma cells. We found that nifurtimox and TM are cytotoxic to D283 and DAOY medulloblastoma cells in a concentration-dependent manner. When nifurtimox and TM are combined, cytotoxicity and ROS production are increased in these cell lines. Based on the isobologram data, nifurtimox and TM function synergistically. In support of the cell viability studies, the combination of nifurtimox and TM increases the amount of cleaved caspase-3 as compared to nifurtimox or TM alone, demonstrating that the loss in cell viability is due to synergistically enhanced apoptosis. The production of ROS causes the decrease in cell viability. As shown by DCF, nifurtimox and TM induce the production of ROS. When nifurtimox and TM are added in combination, the amount of ROS generated in medulloblastoma cells is greater than either treatment alone. Pretreatment of cells with NAC, an antioxidant, followed by treatment with nifurtimox or the combination of nifurtimox and TM, reverses the loss in cell viability. Therefore, the combination of nifurtimox and TM treatment functions synergistically to generate an excessive amount of ROS, which causes the medulloblastoma cells to undergo apoptosis leading to a decrease in cell viability.

Microarray data from medulloblastoma cells treated with nifurtimox and the combination of nifurtimox and TM confirms the mechanism of ROS generation. Adaptive oxidative stress response genes are induced in an effort to detoxify ROS, prevent free radical generation, and facilitate cell survival. The microarray analysis was performed six hours after treatment, so it represents an early cellular response. Several Nrf2 target genes, as well as other genes involved in apoptosis, DNA damage, oxidative stress, and protein folding, are induced by nifurtimox and nifurtimox plus TM combination treatment. These results are comparable to a study that investigated the in vivo gene expression of oxidative stress in mice treated with diquat, a redox cycler, and Sod1-/- mice (40). Similar to our results in nifurtimox and TM treated medulloblastoma cells, up-regulation in several antioxidant genes, including Srxn1, Gclc, Txn2, and HMOX-1, in SOD1-/- mice has been shown (40).

Specifically, nifurtimox and nifurtimox plus TM combination treatment causes up-regulation of several target genes of the Nrf2 pathway, regarded as the most important pathway in protecting cells against oxidative stress (41-45). Using Ingenuity software to analyze the microarray data in a nonrandom fashion, this pathway was regarded as the most highly involved pathway. Nrf2 is a basic leucine zipper transcription factor that binds to the antioxidant response element (ARE) in its target genes and regulates gene expression (42,46-52). Nrf2 target genes up-regulated at least 2 -fold by nifurtimox and TM combination treatment include HMOX1, GCLM, SRXN1, HERPUD1, AFT3, DNAJB1, and SLC7A11. Some of these $\mathrm{Nrf} 2$ target genes are increased by nifurtimox treatment alone.
However, more Nrf2 target genes are up-regulated by nifurtimox plus TM combination treatment. For example, HMOX1 and GCLM expression increased in nifurtimox and nifurtimox plus TM treatment, but not TM treatment alone. These two genes were more up-regulated by nifurtimox alone (HMOX1 6.07-fold, GCLM 3.13-fold) than by nifurtimox plus TM combination treatment (HMOX1 3.55-fold, GCLM 2.11-fold), which may contribute to the decrease in cell survival seen in the combination treatment. Both HMOX1 and GCLM play important antioxidant roles in the cell. Up-regulation of these antioxidant genes that aid in cell survival signifies that the cells are under oxidative stress $(7,8)$. HMOX1 is an antioxidant enzyme involved in the heme degradation process and confers resistance to stress-mediated cell injury $(42,46,53)$. HMOX1 can also be induced by AP-1, NF- $\kappa \mathrm{B}$, and their upstream kinases (ERK, JNK, p38MAPK, PI3K/Akt, PKC) (54). GCLM is the modulatory subunit of glutamate cysteine ligase, which catalyzes the first rate-limiting step of glutathione synthesis $(55,56)$. GSH is the most abundant non-protein thiol in cell, and plays an essential role in the protection of cells against toxicants and metabolism of reactive compounds through reduction and conjugation reactions by reducing hydrogen peroxide and lipid hydroperoxides $(8,57)$. Depletion of GSH by conjugation and reduction reactions results in an increased production of GSH (57). It is likely that nifurtimox and TM treatment depleted the GSH stores in the medulloblastoma cells. An increase in GSH levels serves as an adaptive response for the cell to defend itself against subsequent stresses.

In addition to the antioxidant genes HMOX1 and GCLM, two other antioxidant genes, SRXN1 and TXNIP, are regulated by nifurtimox, TM, and nifurtimox plus TM combination treatment. SRXN1 (sulfiredoxin 1) expression is up-regulated to the same levels with nifurtimox and combination treatment (2.16-fold), but unchanged with TM treatment. Recent studies have identified SRXN1 as a new Nrf2 target gene (58). Sulfiredoxin restores inactive peroxiredoxins (peroxidases) back to the thioredoxin cycle to prevent permanent oxidative inactivation of peroxiredoxins (58). In this way, sulfiredoxin and thioredoxin work in conjunction. The expression of TXNIP (thioredoxin-interacting protein) is repressed by nifurtimox (1.49-fold) and TM (2.11-fold) treatments alone, while the combination treatment (4.34-fold) showed a greater fold repression than either treatment alone. TXNIP inhibits the reducing activity of thioredoxin (TRX) through direct proteinprotein interaction (59). Thioredoxin reduces ROS through reversible oxidation of thioredoxin at its two cysteine residues; thioredoxin is then reduced by thioredoxin reductase and NADPH (8). Therefore, when TXNIP gene is repressed, TRX expression is increased, leading to increased TRX-reducing activity, and potentially an improved cellular response to oxidative stress (60-63). While TRX is typically involved in inhibiting apoptosis, it can also regulate p53, which controls response of proapoptotic genes (63). It is possible that the synergistic down-regulation of TXNIP by the nifurtimox plus TM combination treatment contributes to the increase in apoptosis and decrease in cell survival. Clearly, both nifurtimox and nifurtimox plus TM combination treatment differentially regulate the expression of various antioxidant genes, which may affect the cellular response to oxidative damage and cell survival. 
Additional Nrf 2 target genes are up-regulated by nifurtimox and nifurtimox plus TM treatment, including SLC7A11, HERPUD1, and ATF3 (Table I). HERPUD1 expression is upregulated in response to the accumulation of unfolded proteins in the endoplasmic reticulum (ER) as part of the ER stress response (64). SLC7A11 is a member of the heteromeric $\mathrm{Na}^{+}-$ independent anionic amino acid transport system, where it exchanges cystine for glutamate, which ultimately enhances glutathione synthesis (65). Of these, SLC7A11 was up-regulated similarly by nifurtimox and nifurtimox plus TM treatment, while HERPUD1 and particularly ATF3 were more up-regulated by the nifurtimox plus TM combination treatment. ATF3, which is a bZIP-containing ATF/CREB family transcription factor, is a stress-responsive gene, as well as a p53 target gene with both protective and proapoptotic effects (66-71). Up-regulation of these Nrf2 target genes by the nifurtimox plus TM combination treatment may signify the increased oxidative stress caused by this treatment.

Microarray data also shows a change in gene expression of other genes involved in oxidative stress, DNA damage, apoptosis, protein folding, and nucleosome formation in cells treated with nifurtimox, TM, and the combination of nifurtimox and TM. Some of these genes are differentially regulated by nifurtimox or TM treatment alone, but all of them are significantly regulated at least 2-fold by the nifurtimox plus TM combination treatment (Table I). For example, NR4A2, an orphan nuclear receptor, is up-regulated 2.27-fold $(\mathrm{p}=0.002)$ by the combination treatment, but only 1.27 -fold by nifurtimox and 1.18 -fold by TM treatment. DUSP1 (also known as mkp-1) is the MAPK phosphatase-1, a nuclear phosphatase that dephosphorylates proteins of the MAPK family (p38 MAPK, JNK, ERK1/2) and thereby inactivates them, which may contribute to changes in cell cycle, cellular proliferation, and cell survival (72). The expression is slightly increased with nifurtimox (1.31-fold) or TM (1.18-fold) treatment alone, but is further increased in the combination treatment (2.31-fold). Typically DUSP1 expression is induced by oxidative stress and DNA damaging agents (72). OBFC2A (also known as hSSB2) showed similar expression pattern as DUSP1, slightly increased with nifurtimox (1.2-fold) or TM (1.61-fold) treatment alone, but increased more in the combination treatment (2.24-fold). While it is thought that this protein functions as a single-stranded DNA-binding protein to participate in the DNA damage response, the mechanism is unclear (73).

Three different DNA damage inducible genes, DDIT3, DDIT4, and GADD45B, showed the greatest level of expression in cells treated with the combination of nifurtimox and TM. This provides further evidence that DNA damage was likely induced, which could contribute to an increase in apoptosis. Furthermore, three stress-inducible molecular chaperones involved in protein folding, DNAJB1, DNAJB4, and DNAJB9, were increased by nifurtimox plus TM treatment. As molecular chaperones, these proteins bind to unfolded proteins or mutant proteins to ensure proper protein folding $(74,75)$. Since oxidative stress causes the accumulation of damaged proteins, the upregulation of these genes signifies a cytoprotective response to the proteotoxic stress induced by the nifurtimox plus TM treatment. Of potential interest is the down-regulation of several histones with the nifurtimox plus TM treatment. The histones HIST3H2BB, HIST1H2BF, HIST1H1B, HIST1H2BL,
HIST1H2BM, HIST1H2AB, HIST1H3B, HIST1H2AL, HIST1H1D were down-regulated by at least 2-fold with significant p-values of 0.004-0.04, with the exception of HIST3H2BB, which had a p-value of 0.14 . The downregulation of histone genes may affect nucleosome formation and cell replication. However, because of the complexity of histone gene clusters and the numerous copies of each histone gene, further validation of histone protein levels is necessary to confirm this result. The differential regulation of several genes involved in apoptosis, DNA damage, oxidative stress, protein folding, and nucleosome formation by the combination treatment further demonstrates the synergistic effect of nifurtimox and TM.

While it is clear from the cell viability data that nifurtimox and TM treatment are synergistic, the microarray data provide a genomic snapshot of this synergism. Certain target genes, including NR4A2, DUSP1, DDIT4, GADD45B, ATF3, DNAJB9, HIST3H2BB, and HIST2H2BE, appear to be differentially regulated in a synergistic manner by nifurtimox and TM combination treatment as compared to either treatment alone. Furthermore, it is obvious that the cells are responding to oxidative stress by turning on several different antioxidant genes, particularly targets of the Nrf2 pathway. Based on the data, the combination of nifurtimox and TM generates an overwhelming level of ROS which results in oxidative stress. It is possible that earlier or later time points than $6 \mathrm{~h}$ might provide more insight into the mechanism by which these two drugs function synergistically to decrease the viability by inducing apoptosis of medulloblastoma cells. Further experiments are underway to develop the combination of nifurtimox and TM as a potential treatment for medulloblastoma.

\section{Acknowledgements}

We thank Erika Currier for careful data analysis and Barton Kamen and Rae Nishi for critical reading of the manuscript. We also thank Scott Tighe of the Vermont Genetics Network. This publication was made possible by the Vermont Genetics Network through Grant no. P20 RR16462 from the INBRE Program of the National Center for Research Resources (NCRR), a component of the National Institutes of Health (NIH). Its contents are solely the responsibility of the authors and do not necessarily represent the official views of NCRR and NIH.

\section{References}

1. CBTRUS Supplement Report: Primary Brain Tumors in the United States. Central Brain Tumor Registry of the United States, Hindsdale, IL, 2004.

2. McNeil DE, Cote TR, Clegg L and Rorke LB: Incidence and trends in pediatric malignancies medulloblastoma/primitive neuroectodermal tumor: a SEER update. Surveillance Epidemiology and End Results. Med Pediatr Oncol 39: 190-194, 2002.

3. Grill J and Bhangoo R: Recent developments in chemotherapy of paediatric brain tumors. Curr Opin Oncol 19: 612-615, 2007.

4. Mulhern RK, Palmer SL, Merchant TE, et al: Neurocognitive consequences of risk-adapted therapy for childhood medulloblastoma. J Clin Oncol 23: 5511-5519, 2005.

5. Ribi K, Relly C, Landolt MA, Alber FD, Boltshauser E and Grotzer MA: Outcome of medulloblastoma in children: long-term complications and quality of life. Neuropediatrics 36: 357-365, 2005.

6. Pan JS, Hong MZ and Ren JL: Reactive oxygen species: a doubleedged sword in oncogenesis. World J Gastroenterol 15: 1702-1707, 2009. 
7. Kaspar JW, Niture SK and Jaiswal AK: Nrf2:INrf2 (Keap1) signaling in oxidative stress. Free Radic Biol Med 47: 1304-1309, 2009.

8. Circu ML and Aw TY: Reactive oxygen species, cellular redox systems, and apoptosis. Free Radic Biol Med 48: 749-762, 2010.

9. Fang J, Seki T and Maeda $\mathrm{H}$ : Therapeutic strategies by modulating oxygen stress in cancer and inflammation. Advanced Drug Deliv Rev 61: 290-302, 2009.

10. Mates JM, Segura JA, Alonso FJ and Marquez J: Intracellular redox status and oxidative stress: implications for cell proliferation, apoptosis, and carcinogenesis. Arch Toxicol 82: 273-299, 2008.

11. Lau AT, Wang Y and Chiu JF: Reactive oxygen species: current knowledge and applications in cancer research and therapeutic. J Cell Biochem 104: 657-667, 2008.

12. Raether W and Hanel H: Nitroheterocyclic drugs with broad spectrum activity. Parasitol Res 90: 19-39, 2003.

13. Maya JD, Bollo S, Nunez-Vergara LJ, Squella JA, Repetto Y, Morello A, Perie J and Chauviere G: Trypanosoma cruzi: effect and mode of action of nitroimidazole and nitrofuran derivatives. Biochem Pharmacol 65: 999-1006, 2003.

14. Ramakrishna Rao DN and Mason RP: Generation of nitro radical anions of some 5-nitrofurans, 2- and 5-nitroimidazoles by norepinephrine, dopamine, and serotonin. J Biol Chem 262: 11731-11736, 1987.

15. Saulnier Sholler GL, Kalkunte S, Greenlaw C, McCarten K and Forman E: Antitumor activity of nifurtimox observed in a patient with neuroblastoma. J Pediatr Hematol Oncol 28: 693-695 2006

16. Saulnier Sholler GL, Brard L, Straub JA, Dorf L, Illenye S, Koto K, Kalkunte S, Bosenberg M, Ashikaga T and Nishi R: Nifurtimox induces apoptosis of neuroblastoma cells in vitro and in vivo. J Pediatr Hematol Oncol 31: 187-193, 2009.

17. Paulos C, Paredes J, Vasquez I, Thambo S, Arancibia A and Gonzalez-Martin G: Pharmacokinetics of a nitrofuran compound, nifurtimox, in healthy volunteers. Int J Clin Pharmacol Ther Toxicol 27: 454-457, 1989.

18. Prathalingham SR, Wilkinson SR, Horn D and Kelly JM: Deletion of the trypanosoma brucei superoxide dismutase gene sodb1 increases sensitivity to nifurtimox and benznidazole. Antimicrob Agents Chemother 51: 755-758, 2007.

19. Fridovich I: Superoxide radical and superoxide dismutases Annu Rev Biochem 64: 97-112, 1995.

20. Imlay JA and Fridovich I: Assay of metabolic superoxide production in Escherichia coli. J Biol Chem 266: 6957-6965, 1991.

21. Fridovich I: The biology of oxygen radicals. Science 201: 875-880, 1978.

22. Chidambaram MV, Barnes G and Frieden E: Inhibition of ceruloplasmin and other copper oxidases by thiomolybdate. J Inorg Biochem 22: 231-239, 1984.

23. Brewer GJ, Askari F, Dick RB, Sitterly J, Fink JK, Carlson M, Kluin KJ and Lorincz MT: Treatment of Wilson's disease with tetrathiomolybdate: V.control of free copper by tetrathiomolybdate and a comparison with trientine. Translational Res 154: 70-77, 2008.

24. Gartner EM, Griffith KA, Pan Q, Brewer GJ, Henja GF, Merajver SD and Zalupski MM: A pilot trial of the anti-angiogenic copper lowering agent tetrathiomolybdate in combination with irinotecan, 5-fluoracil, and leucovorin for metastatic colorectal cancer. Invest New Drugs 27: 159-165, 2009.

25. Redman BG, Esper P, Pan Q, Dunn RL, Hussain HK, Chenevert T, Brewer GJ and Merajver SD: Phase II trial of tetrathiomolybdate in patients with advanced kidney cancer. Clin Cancer Res 9: $1666-1672,2003$

26. Brewer GJ, Dick RD, Grover DK, et al: Treatment of metastatic cancer with tetrathiomolybdate, an anticopper, antiangiogenic agent: phase I study. Clin Cancer Res 6: 1-10,2006.

27. Lowndes SA, Adams A, Timms A, et al: Phase I study of copper-binding agent ATN-224 in patients with advanced solid tumors. Clin Cancer Res 14: 7526-7534, 2008.

28. Pass HI, Brewer GJ, Dick R, Carbone M and Merajver S: A phase II trial of tetrathiomolybdate after surgery for malignant mesothelioma: final results. Ann Thorac Surg 86: 383-390, 2008.

29. Kurisaka M and Mori K: Immunohistochemical study of medulloblastoma with a monoclonal antibody against human copper and zinc-superoxide dismutase. Neurol Med Chir 36 220-223, 1996

30. Hileman EO, Liu J, Albitar M, Keating MJ and Huang P: Instrinsic oxidative stress in cancer cells: a biochemical basis for therapeutic selectivity. Cancer Chemother Pharmacol 53: 209-219, 2004.
31. Dincer Z: Copper toxicity in sheep: studies on copper chelation by ammonium tetrathiomolybdate (TTM) and metallothionein. [dissertation]. University of Liverpool, Liverpool, 1994.

32. R Development Core Team. R: A Language and Environment for Statistical Computing. Available from: http://www.R-project.org, 2009.

33. Gentleman RC: Bioinformatics and computational biology solutions using R and Bioconductor, in statistics for biology and health. Springer Science \& Business Media, New York, 2005.

34. Gentleman RC, Carey VJ, Bates DM, Bolstad B, Dettling M, Dudoit S, Ellis B, Gautier L, Ge Y, Gentry J, Hornik K, Hothorn T, Huber W, Iacus S, Irizarry R, Leisch F, Li C, Maechler M, Rossini AJ, Sawitzki G, Smith C, Smyth G, Tierney L, Yang JY and Zhang J: Bioconductor: open software development for computational biology and bioinformatics. Genome Biol 5: R80, 2004

35. Irizarry RA, Bolstad BM, Collin F, Cope LM, Hobbs B and Speed TP: Summaries of Affymetrix GeneChip probe level data. Nucleic Acids Res 31: 5, 2003.

36. Bolstad BM, Irizarry RA, Astrand M and Speed TP: A comparison of normalization methods for high density oligonucleotide array data based on variance and bias. Bioinformatics 19: 185-193, 2003.

37. Bengtsson H, Simpson K, Bullard J and Hansen K: Aroma. Affymetrix: a generic framework in $\mathrm{R}$ for analyzing small to very large Affymetrix data sets in bounded memory, in Technical Report \#745. Department of Statistics, University of California, Berkeley, 2008.

38. Wilson CL and Miller CJ: Simpleaffy: a BioConductor package for Affymetrix quality control and data analysis. Bioinformatics 21: 3683-3685, 2005

39. Thornberry NA and Lazebnik Y: Caspases: enemies within. Science 281: 1312-1316, 1998.

40. Han ES, Muller FL, Perez VI, et al: The in vivo gene expression signature of oxidative stress. Physiol Genom 34: 112-126, 2008.

41. Jaiswal AK: Nrf2 signaling in coordinated activation of antioxidant gene expression. Free Radic Biol Med 36: 1199-1207, 2004.

42. Dhakshinamoorthy S, Long DJ and Jaiswal AK: Antioxidant regulation of genes encoding enzymes that detoxify xenobiotics and carcinogens. Curr Top Cell Regul 36: 201-206, 2000.

43. Zhang DD: Mechanistic studies of the Nrf2-Keap1 signaling pathway. Drug Metab Rev 38: 769-789, 2006.

44. Kobayashi $M$ and Yamamoto M: Nrf2-Keap1 regulation of cellular defense mechanisms against electrophiles and reactive oxygen species. Adv Enzyme Regul 46: 113-140, 2006.

45. Copple IM, Goldring CE, Kitteringham NR and Park BK: The Nrf2-Keap1 defense pathway: role in protection against druginduced toxicity. Toxicology 246: 24-33, 2008.

46. Jaiswal AK: Regulation of genes encoding NAD(P)H:quinone oxidoreducatases. Free Radic Biol Med 29: 252-254, 2000.

47. Bloom D, Dhakshinamoorthy S, Wang W, Celli CM and Jaiswal AK: Role of NF-E2 related factors in oxidative stress. In: Cell and Molecular Responses to Stress, Protein Adaptation and Signal Transduction. Storey KB and Storey JM (eds). Elsevier, Amsterdam, pp229-238, 2001.

48. Venugopal R and Jaiswal AK: Nrf1 and Nrf2 positively and c-Fos and Fra1 negatively regulate the human antioxidant response element-mediated expression of NAD(P)H:quinone oxidoreductase 1 gene. Proc Natl Acad Sci USA 93: 14960-14965, 1996.

49. Alam J, Stewart D, Touchard C, Boinapally S, Choi MK and Cook JL: Nrf2, a Cap'n'Collar transcription factor, regulates induction of the heme oxygenase-1 gene. J Biol Chem 274: 26071-26078, 1999.

50. Wild AC, Moinova HR and Mulcahy RT: Regulation of g-glutamylcysteine synthetase subunit gene expression by transcription factor Nrf2. J Biol Chem 274: 33627-33636, 1999.

51. Nguygen T, Huang HC and Pickett CB: Transcriptional regulation of the antioxidant gene response element: activation by Nrf2 and repression by MafK. J Biol Chem 275: 15466-15473, 2000.

52. Andrews NC, Erdjument-Bromage H, Davidson MB, Tempst $\mathrm{P}$ and Orikin SH: Erythroid transcription factor NF-E2 is a haematopoietic-specific basic leucine zipper protein. Nature 339: 722-727, 1993.

53. Tenhunen R, Marver MS and Schmid R: The enzymatic conversion of heme to bilirubin by microsomal heme oxygenase. Proc Natl Acad Sci USA 61: 748-755, 1968

54. Prawan A, Kundu JK and Surh YJ: Molecular basis of heme oxygenase-1 induction: implications for chemoprevention and chemoprotection. Antioxidants Redox Signaling 7: 1688-1703, 2005.

55. Lu SC: Regulation of glutathione synthesis. Molecular Aspects Medicine 30: 42-59, 2009. 
56. Krzywanski DM, Dickinson DA, Iles KE, Wigley AF, Franklin CC, Liu RM, Kavanagh TJ and Forman HJ: Variable regulation of glutamate cysteine ligase subunit proteins affects glutathione biosynthesis in response to oxidative stress. Arch Biochem Biophys 423: 116-125, 2004.

57. Soriano FX, Leveille F, Papadia S, Higgins LG, Varley J, Baxter P, Hayes JD and Hardingham GE: Induction of sulfiredoxin expression and reduction of peroxiredoxin hyperoxidation by the neuroprotective $\mathrm{Nrf} 2$ activator $3 \mathrm{H}$-1,2-dithiole-3-thione. J Neurochem 107: 533-543, 2008.

58. Park JW, Mieyal JJ, Rhee SG and Chock PB: Deglutathionylation of 2-Cys peroxiredoxin is specifically catalyzed by sulfiredoxin. J Biol Chem 284: 23364-23374, 2009.

59. Nishiyama A, Matsui M, Iwata S, Hirota K, Masutani H, Nakamura H, Takagi Y, Sono H, Gon Y and Yodoi J: Identification of thioredoxin-binding protein-2/vitamin $\mathrm{D}(3)$ upregulated protein 1 as a negative regulator of thioredoxin function and expression. J Biol Chem 274: 21645-21650, 1999.

60. Patwari P, Higgins LJ, Chutkow WA, Yoshioka J and Lee RT: The interaction of thioredox in with Txnip. Evidence for formation of a mixed disulfide by disulfide exchange. J Biol Chem 281: 21884-21891, 2006.

61. Junn E, Han SH, Im JY, Yang Y, Cho EW, Um HD, Kim DK, Lee KW, Han PL, Rhee SG and Choi I: Vitamin D3 upregulated protein 1 mediates oxidative stress via suppressing the thioredoxin function. J Immunol 164: 6287-6295, 2000.

62. Mitsui A, Hamuro J, Nakamura H, Kondo N, Hirabayashi Y, Ishizaki-Koizumi S, Hirakawa T, Inoue T and Yodoi J: Overexpression of human thioredoxin in transgenic mice controls oxidative stress and life span. Antioxid Redox Signal 4: 693-696, 2002.

63. Tonissen KF and Di Trapani G: Thioredoxin system inhibitors as mediators of apoptosis for cancer therapy. Mol Nutr Food Res 53: 87-103, 2009

64. Hong SH, Kim J, Kim JM, Lee SY, Shin DS, Son KH, Han DC, Sung YK and Kwon BM: Apoptosis induction of 2'-hydroxycinnamaldehyde as a proteosome inhibitor is associated with ER stress and mitochondrial perturbation in cancer cells. Biochem Pharmacol 74: 557-565, 2007.

65. Lo M, Ling V, Wang YZ and Gout PW: The Xc-cystine/glutamate antiporter: a mediator of pancreatic cancer growth with a role in drug resistance. Br J Cancer 99: 464-472, 2008.
66. Kim KH, Jeong JY, Surh YJ and Kim KW: Expression of stressresponse ATF3 is mediated by Nrf2 in astocytes. Nucleic Acids Res 38: 48-59, 2010.

67. Turchi L, Aberdam I, Mazure N, Pouyssegur J, Deckert M, Kitajima S, Aberdam D and Virolle T: Hif-2alpha mediates UV-induced apoptosis through a novel ATF3-dependent death pathway. Cell Death Differ 15: 1472-1480, 2008.

68. Yoshida T, Sugiura H, Mitobe M, et al: ATF3 protects against renal ischemia-reperfusion injury. J Am Soc Nephrol 19: 217-224, 2008.

69. Lu D, Wolfgang CD and Hai T: Activating transcription factor 3 , a stress-inducible gene, suppresses Ras-stimulated tumorigenesis. J Biol Chem 281: 10473-10481, 2006.

70. Nakagomi S, Suzuki Y, Namikawa K, Kiryu-Seo S and Kiyama $\mathrm{H}$ : Expression of the activating transcription factor 3 prevents c-Jun $\mathrm{N}$-terminal kinase-induced neuronal death by promoting heat shock protein 27 expression and Akt activation. J Neurosci 23: 5187-5196, 2003.

71. Seijffers R, Mills CD and Woolf CJ: ATF3 increases the intrinsic growth rate of DRG neurons to enhance peripheral nerve regeneration. J Neurosci 27: 7911-7920, 2007.

72. Boutros T, Chevet E and Metrakos P: Mitogen-activated protein (MAP) kinase/MAP kinase phosphatase regulation: roles in cell growth, death, and cancer. Pharmacol Rev 60: 261-310, 2008.

73. Li Y, Bolderson E, Kumar R, Muniandy PA, Xue Y, Richard DJ, Seidman M, Pandita TK, Khanna KK and Wang W: hSSB1 and hSSB2 form similar multiprotein complexes that participate in DNA damage response. J Biol Chem 284: 23525-23531, 2009.

74. Ohtsuka K and Suzuki T: Roles of molecular chaperones in the nervous system. Brain Res Bull 53: 141-146, 2000.

75. Mitra A, Shevde LA and Samant RS: Multi-faceted role of HSP40 in cancer. Clin Exp Metastasis 26: 559-567, 2009.

76. Saulnier Sholler GL, Bergendahl GM, Brard L, Singh AP, Heath BW, Bingham PM, Ashikaga T, Kamen BA, Homans AC, Slavik MA, Lenox SR, Higgins TJ and Ferguson WS: A phase 1 study of nifurtimox in patients with relapsed/refractory neuroblastoma. J Pediatr Hematol Oncol 33: 25-30, 2011. 